\title{
Determinants Of Personality Traits Influence On Entrepreneurial Intentions Among Agricultural Students Evidence From Two Different Economies
}

\author{
Ghulam Raza Sargani ${ }^{1}$, Deyi Zhou ${ }^{2}$, Tehmina Mangan ${ }^{3}$, and Habibullah Rajper ${ }^{4}$
}

\begin{abstract}
Unemployment is a significant problem considered in many emerging economies. The joblessness mishap, especially in massive youth populace countries like China and Pakistan, which recently facing challenging situations in job creation. The youths are key players to create a vital role in the devotion to self-employment, to achieve financial independence and benefits to the economy. Entrepreneurship is a genuine alternative to escalation living standard among masses. In essential prospective entrepreneurship in the agricultural sector to be equipped, especially for faculty students to solve the problem of unemployment from rural graduates. The purpose of this research study to evaluate personality traits influence on entrepreneurial intentions among agricultural graduates profession choice in agriculture as a self-employment avenue to become an entrepreneur in the future. To this study, primary survey methodology used on a voluntary based participant's sample, consisting of $\mathbf{6 4 0}$ graduate students. The data collected from Sindh Agriculture University (SAU) Pakistan and Huazhong Agricultural University (HZAU) China. This study employed entrepreneurial intention, dependent variable on alertness, creativity, locus of control, risk-taking propensity, and need for achievement, with set control variables. Accumulated data analyzed by using multiple coefficient regressions analysis descriptive statistics and independent $t$ Tests. Conferring to results, overall reliability 0.86 found a significant favorable influence of entrepreneurial intentions among graduates. Higher entrepreneurial alertness, intense creativity, moderate propensity to take the risk, more significant locus of control and superior need for achievement, compared with individuals who do not possess such intentions between male and female of China and Pakistan students towards agriculture.
\end{abstract}

Index Terms - Entrepreneurial Intentions, Personality Traits, Independent t-Test, Agriculture

\section{INTRODUCTION}

Entrepreneurship interest increasing in agricultural anticipated driving human source efficiency, due to the low contribution of fledgling young generation phenomenon in agriculture. Today's graduate is tomorrow's potential entrepreneur; the youths are key players to create a vital role in devotion to self-employment, and to achieve financial independence in society and benefits to the rural economy, therefore the entrepreneurship; is the correct alternative to escalation living standard among masses. Entrepreneurship is

1. College of Economics and Management, Huazhong Agricultura University, Wuhan, 430070, PR China; razasargani@gmail.com

2. College of Economics and Management, Huazhong Agricultural University, Wuhan, 430070, PR China; zhoudeyi@aliyun.com

3. Department of Agricultural Economics, Faculty of Agricultural Social Sciences, Sindh Agriculture University, Tandojam, 70060, Pakistan t.economist@hotmail.com an essential prospect agricultural sector to be equipped, mainly to solve the problem of unemployment from rural graduates. The main objective of this study is to evaluate personality traits influence of entrepreneurial intentions among agricultural graduates profession choice in agriculture as a self-employment avenue in the future.

The questions of economic sustainability, rural development prospects remain present themes in the socioeconomic of existing agriculture Girvan et al., (2009) which accounts, 60 percent of national income and approximately $70 \%$ of labor force directly and indirectly involved to this sector in both China and Pakistan. The global entrepreneurship monitor (Molino, Dolce, Cortese, \& Ghislieri, et al., 2018) reported that there are less opportunitydriven entrepreneurs in Pakistan as compared to counterpart China. However, Pakistan's GEDI (15.6) is less than China's GEDI (41.1). The diversity among the nation in their physical cultural-context that agriculture plays a functional role in sustainable rural economic development and growth (Syrquin et al., 1988) estimated three phases of economic development and growth primarily agricultural production based products and small-scale manufacturing; secondly agricultural shift to manufacturing, thirdly innovation in the services sector. The novelty business environment and replications in the region are entrepreneurial events. Both economies are going through these phases were mostly relying on manufacturing but agriculture. China's economy is progressing more than the economy of Pakistan. (Yusof, Sandhu, \& Jain et al., 2007) Identified that considering to entrepreneurship as a mediator of revitalizing the social economy, as a means of solving the unemployment problem of rural graduates a potential catalyst for product and market innovation, and an incubator for agricultural progress generally seen as an instrument of social-economic adjustment of employment and job settlements. (Levenburg \& Schwarz et al.,2008) The current predicament corresponds to the rapid rise of food fuels and prices, which poses a severe threat to people's social standards and increases the need for expansion of entrepreneurial projects and program for new entrants in the country.

Agriculture sector offers numerous self-employment opportunities, prospects to individual and the economy as a

4. Department of Agricultural Economics, Faculty of Agricultural Social
Sciences, Sindh Agriculture University, Tandojam, 70060, Pakistan hmagsi@gmail.com 
whole, it enhances the small businesses, to flourish in the market economy because high businesses supplies to labor demands (Sargani et al., 2018) Though some drawbacks in entrepreneurship, but individuals are still preferring to be an entrepreneur whereas intention indicates a substantial role in that career choice. The purpose of this study is to reveal the factors affecting students' entrepreneurial intentions and to examine the differences in entrepreneurial intentions of agricultural graduates under different cultural backgrounds to explore the entrepreneurial intentions of young people who are more enthusiastic about self-employment (Blanchflower, Oswald, \& Stutzer et al., 2001). Therefore, while cultivating potential entrepreneurs in the future, it is of specific reference to examine the students' entrepreneurial intentions. This study takes agricultural graduates as the research object and studies the influence of personality traits on entrepreneurial willingness, to create entrepreneurial career choices in the agricultural field. This study used Huazhong Agricultural University (HZAU), China and Sindh Agricultural University (SAU) as a sample to investigate the understanding of the theme of agricultural entrepreneurship graduates, and examined the hypothesis, research methods and results of the theme of agricultural entrepreneurship graduates discovery limitation and policy discussion.

\section{LITERATURE REVIEW}

\section{A. ENTREPRENEURIAL INTENTION DEVELOPMENT}

For rural development and growth, new business creation is one of the most dynamic drivers of investing the necessary time and effort in creating new things that enterprise cognitive business and shared risk values. (Hisrich, Langan-Fox, \& Grant et al., 2007), (Charney \& Libecap et al., 2003)and (Hannon, Collins, \& Smith, et al., 2005) explained that understanding entrepreneurship is the main key factor in the development and cultivation of entrepreneurship. Entrepreneurship education plays a significant role in the rural economy. Therefore, (Kuratko, 2005; Zakaria et al., 2014) began to inspire that entrepreneurship, and some aspects of it can be taught. Also (Carvalho et al., 2006) assumed that the entrepreneurial role achieved and accepted through experimental and cultural training and education in rural graduates.

\section{B. Intention}

According to (Ajzen, 1991), the intention is related to cognition and risk-intensive processes, including beliefs, perceptions, and actions where creation is the necessary premise of entrepreneurial behavior. Whereas (Sardeshmukh \& Smith et al., 2010) said that it is essential to understand entrepreneurial behavior during the creation of entrepreneurial intentions. (Şenyuva \& Çalışkan et al., 2014) The intent is an indicator of individual behavioral tendencies. The concept of intentionality (Bird et al.,1988) described as state of mind, significant attention, experience, and action on the specific pathways, and goals of its achievements.

\section{Entrepreneur}

An individual who starts a new business having excellent flexibility, creativeness, and inventiveness, for a business called an entrepreneur. (Butler, Doktor, \& Lins, et al., 2010) To become an entrepreneur when an individual can intend to the expectation of the entrepreneurship is pleasurable, taking the risk, the working hard to increase the income to gain the autonomy in the society (Venesaar, Kolbre, \& Piliste, et al., 2006).

\section{Entrepreneurship Career Choice in agriculture}

In general, agriculture is considered a less promising industry for young people but the self-employment has significant value in agriculture for the entire economy and individuals who set up their business to achieve sustainable socio-economic growth and development. (Ridha \& Wahyu, et al., 2017) Investigated individuals who are willing to study the choice of carriers in organic agriculture as their selfemployment, especially as a financial issue, and need to determine that agriculture can create a decent standard of living for young people. Therefore, the lack of capital, skills, support, market opportunities, and risks is considered to be a significant obstacle, hindering youth entrepreneurship seeking to seek financial returns in the agricultural sector (Ahmed et al., 2010). However, agriculture, considered to be a high-risk investment and return, is a sensitive issue, so most rural youths tend to operate in other industries (Dufur, Parcel, $\&$ Troutman et al., 2013). This condition has become a reference for research, and agriculture has great potential and interest due to the financial problems of young graduates. It may be a response to the entrepreneurial crisis in the agricultural sector, paralleling the entrepreneur's agricultural will.

Entrepreneurship is the main engine that adds many economies, in competitiveness, creativity, innovation, rural development, and growth (Porter et al.,1998). However, (Gorman, Hanlon, \& King, et al., 1997) and (Karanassios, Pazarskis, Mitsopoulos, \& Christodoulou et al., 2006) showed in their results that economic tumors in employment, job creation, technological change, and survival of living masses have a positive relationship with entrepreneurship. The various characteristics have a significant impact on (selfemployed) career choices and are psychological factors associated with the entrepreneurs. The proposed concept by (Bygrave and Hofer et al., 1992) includes trends in risk-taking (internal, internal) control points, creativity, and achievement needs, while (Robinson, Stimpson, Huefner, \& Hunt et al.,1991) indicate innovation. Self-confidence, control, and achievement may be the predictive attitude of entrepreneurs. In bringing together literature reviews, alertness, creativity, control points, achievement needs, and risk-taking tendencies are the leading personal psychological characteristics associated with entrepreneurship. 


\section{E. Different Mode of Personality Traits}

\section{1) Entrepreneurial Alertness}

Entrepreneurial alertness defined as an entrepreneurs who have unique talents and abilities in economic behavior, and can recognize the prospects of entrepreneurship, so that market participants can get more returns in various situations that have not been noticed so far (Kirzner et al.,) introducing a background in entrepreneurship that enables people to synthesize information from multiple sources and alert people to discover, which helps humans to pay more attention to entrepreneurial information and improve acceptance (Ardichvili, Cardozo, \& Ray, et al., 2003). Alertness is an available attitude, but to date, it has been overlooked that opportunities in entrepreneurs maintain an indivisible antenna that perceives the prospect of continuous observation of potential observations of potential environmental changes associated with possible activities. (Kirzner, et al., 1997). Therefore, even in the case of profitability, the basis of the entrepreneur's alertness to opportunities makes the individual an entrepreneur. (G. E. Hills, G. T. Lumpkin, \& R. P. Singh, et al., 1997) Entrepreneur's specific alertness to business opportunities in learning. However, (Sargani et al., 2018) reported the mediating effect of gender entrepreneurial alertness, which is an essential relationship between intention and alertness.

\section{2) Entrepreneurial Creativity}

Entrepreneurial creativity has uncertainty and ambiguity in the decision-making process. Corresponding to the non-linear response of entrepreneurs to the business world, it often motivates the investigation of intention and creativity within the dynamic range of entrepreneurial environment(PerrySmith \& Shalley et al., 2003). For business success, creativity plays an essential role in identifying opportunities. (Porter et al., 1998) Revealed the perseverance of research on the impact of creativity on economic efficiency (Bird et al., 1988) which leads to the immediate success of stability between imagination and intelligence, thus creating force observes the impact of creativity on entrepreneurial activities based on students' entrepreneurial will, and through their selfperceived creativity. The study found that graduate entrepreneurial tendencies influenced by creativity, while in the agricultural sector; creativity is seen as a significant contributor to economic employment and growth, with inconsistent attitudes. The creativity that motivates the critical intent process needs to be considered (Sargani et al., 2018). Pointing out that entrepreneurial creativity related to entrepreneurial intentions, the second hypothesis of this study is proposed.

\section{3) Need for Achievement}

The need for achievement involves predictions, behaving better than others, or your past performance, which is the most common entrepreneurial character. It is the most influential mediator according to (Hansemark et al.,2003) (Gürol \& Atsan et al., 2006) To succeed in corporate incentives, the researchers pushed the achievement needs to individuals defined by (De Pillis \& Reardon et al., 2007). To take on the expected risks and set realistic responses based on setting appropriate targets, extraordinary achievers. Take personal responsibility for achievement needs. (McClelland, et al., 1962) Studied factors closely related to corporate success behavior, and several studies found differences in the dimensions of achievement incentives and operationalization. Appropriate and reliable links between entrepreneurial behavior, trends, and achievement motivation (Johnson et al.,1990). Numerous studies (Hansemark et al., 1998), and (Littunen et al.,2000) Surveyed non-entrepreneurs and entrepreneurs and found that they have an additional absolute correlation with entrepreneurs need for achievement. According to the study (Gürol \& Atsan, et al., 2006) the investigation reveals a positive relationship between EI and nAch (Hull, Bosley, \& Udell, et al., 1980) and the university student sample identifies the possibility of creating a business in the next three years which is positively related to achievement needs. Given the above, the literature, the third hypothesis of this study is constructed.

\section{4) Risk-taking propensity}

Different personalities characterize entrepreneurs and employees, and they can classify clear choices and actions and take risks in ambiguous situations. (van der Kuip \& Verheul, et al., 1999) Represented the recognition of many risks and uncertainties, and entrepreneurs have the willpower to find and complete business when taking action. However,, (Brockhaus Sr, et al., 1980) and (Littunen, et al., 2000),(Erdem, et al., 2001) pointed out that in an uncertain entrepreneurial situation, with career opportunities, family, relationships, spirit, passion state characteristics and risks associated with economic well-being. (Thomas \& Mueller, et al., 2000) Pointed out that entrepreneurs need to prioritize their business decisions; in the case of extreme risks or uncertainties, they are reluctant to participate in these situations and bear moderate risks. Therefore, entrepreneurs who are not opposed to risking reflect the risk-taking tendency in the proposal, that is, as the mediator's will between (nAch, Alt, LoC) and therefore, the researchers suggest verifying whether young people's attitude toward risk will affect Their entrepreneurial intentions and their essential role in agriculture. Thus, this paper constructs the fourth hypothesis of this study from the perspective of literature.

\section{5) Locus of Control}

The ability to control a particular situation, stimulate the perception of its life to represent the trajectory of control (Pervin, et al., 1970) the prompt control, such as good luck, destiny, luck, and the deliberate setting of individuals with LOC It affects the scope of action throughout the development process and is one of the critical factors in the characteristics.(Rotter, et al., 1966), studied two types of LoC, typical LoC that explain facts, and the behavior that occurs in them through self-behavior, attention, and choice is an internal locus. These characteristics characterize the external locus, that is, the cause of the event is luck, fate or strong, while the participants are beyond the control of the individual.. (Ang \& Hong, et al., 2000) Studies have shown that LOC may affect college students' entrepreneurial intentions (Gürol \& Atsan et al., 2006) entrepreneurial 
intentions and LOC is positively related to those with external control points, which use entrepreneurship The higher the profitability of the regulations is measured.

\section{F. Culture context of developing entrepreneurship}

They are providing sustainable development and growth for the social economy by the needs and needs of its people $(\mathrm{G}$. Hills, G. Lumpkin, \& R. Singh, et al., 1997). With the support of possession, the enormous potential, happiness, and welfare development employability, through the right to fulfill the resilience, form improvement in social life. However, culture can shape human behavior through social policies and practices (Şahin \& Asunakutlu et al., 2014). Influencing entrepreneurs not only through management but also through policies that create jobs for young people, especially in the agricultural sector. The cultural relationship between the state and business personnel is the influencing factor of the size and type of business directly affecting individuals (Sargani et al., 2018) examined the perfect link between entrepreneurship education and youth entrepreneurial willingness. Similarly, the need for achievement attention to the impact of media attention on entrepreneurship has also found a significant impact. On the other hand, the perception of risk-taking, family, and friends has affected the intentions of Pakistani students, but the self-efficacy and entrepreneurial network factors of Chinese graduates. The determinants are important in Chinese, but not among Pakistani graduates. Agricultural enterprise. Therefore, the study emphasizes that graduates in entrepreneurship-related majors are more likely to develop the personality traits needed to create an entrepreneurial career. Thus, this study builds the sixth hypothesis.

\section{G. Facilitating influence on genders' gape entrepreneurship}

In the self-employment gender gap persists worldwide (Obschonka, Schmitt-Rodermund, \& Terracciano, et al., 2014) Despite the relevance of the subject, women's entrepreneurial behavior tends to be low (Obschonka et al., 2014) the low levels of EI for females found by some scholars (Zhao, Seibert, \& Hills, et al., 2005),(Yordanova \& Tarrazon et al., 2010) examined the role in stereotypes gender though, studies have presented evidence to this effect (Díaz-García \& Jiménez-Moreno et al., 2010). There are several psychological backgrounds and situational dynamics in the gender-gaps recognized in entrepreneurship. In terms of market, access gender plays a significant role in supporting entrepreneurial countries (Rosti \& Chelli et al.,2005). Human capital, education and social norms (Wilson, Kickul, \& Marlino et al.,, 2007),(Leoni \& Falk, 2010) and personal characteristics, such as self-efficacy (Wilson et al., 2007) personality traits (Obschonka et al., 2014),(Liñán \& Chen, et al., 2009), adventure and fear of failure (Sargani et al., 2018),(Verheul, Thurik, Grilo, \& Van der Zwan, et al., 2012). The influence of family, friend society, environment, and media inspiration experience, explaining men and the difference in the entrepreneurial spirit of women in business compared with women primarily in terms of developing of countries. (Sargani et al., 2018) And (Marlow et al., 2002). Identified that nowadays men and women's entrepreneurship are not limited to just one gender but because of various economic pressures, women have emerged to achieve family
Survival, its potential is only to work side by side with men. (Buttner, et al., 1993) Said that more and more women are starting to venture around the global awareness of women's entrepreneurship, and (Murphy \& Callaway et al., 2004) found that entrepreneurship between the two genders The high level of confidence has already affected the development of women's entrepreneurship. Therefore, this study proposes seven hypotheses as follows:

\section{H. DeVelopment of Hypotheses}

H1. Agricultural students with entrepreneurial intentions are more alert than agricultural students who do not have entrepreneurial intentions.

H2. Agricultural students with entrepreneurial intentions have greater creativity than agricultural students who do not have entrepreneurial intentions.

H3. Agricultural students with entrepreneurial intentions need more achievements than agricultural students who do not have entrepreneurial intentions.

H4. Agricultural students with entrepreneurial intentions have a higher risk-taking tendency than agricultural students who do not have entrepreneurial intentions.

H5. Agricultural students with entrepreneurial intentions have more control than agricultural students who do not have entrepreneurial intentions.

H6. Compared with, Chinese agricultural students Pakistani students have a higher willingness to start a business.

H7. Male agricultural students have higher entrepreneurial intentions than female

\section{TheORETICAL Model OF THE StUdy}

A research model evaluated by literature review (shown in Figure 1) has been proposed to measure the impact of personality cognition characteristics: alertness (H1), creativity (H2), achievement needs (H3), risk-taking propensity (H4), and locus of control (H5) with a set of control variables Chinese vs Pakistani (H6) and gender (H7) of entrepreneurial intentions among students in the agriculture sector.

FIGURE -1 PROPOSED THEORETICAL MOFRL OF THE STUDY

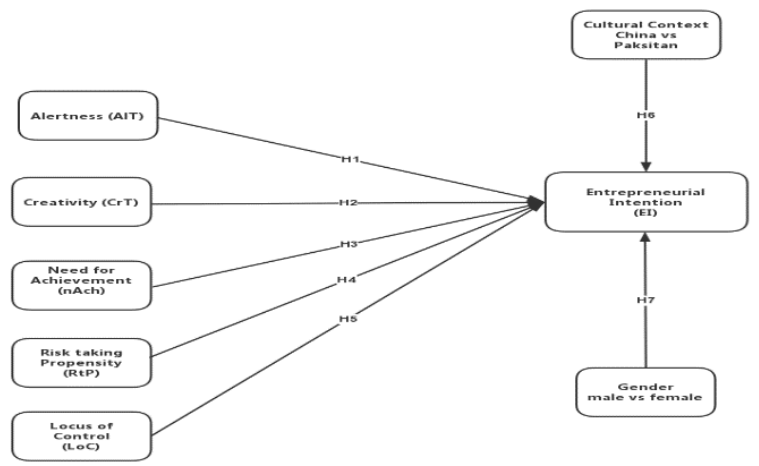

III. MATERIAL AND METHODS

\section{A.Data Collection and Sampling Procedure}

The sample of agricultural university students 320 Huazhong Agricultural University China and 320 Sindh Agriculture University Pakistan of 640 graduates with majoring agricultural disciplines were interviewed by self- 
TABLE I. DEMOGRAPHIC CHARACTERISTICS RESULTS

\begin{tabular}{|c|c|c|c|c|}
\hline \multicolumn{2}{|l|}{ Variables } & \multirow[t]{2}{*}{ N/\%AGE } & \multirow[t]{2}{*}{$\begin{array}{c}\text { Mea } \\
\mathrm{n}\end{array}$} & \multirow[t]{2}{*}{$\begin{array}{l}\text { Std. } \\
\text { Dev. }\end{array}$} \\
\hline \multirow[b]{2}{*}{ Gender } & Male & & & \\
\hline & $\begin{array}{c}\text { Femal } \\
\mathrm{e}\end{array}$ & $297(46.4 \%)$ & \multirow[t]{2}{*}{1.46} & 0.50 \\
\hline \multirow{5}{*}{ Age } & $<20$ & $71(11.1 \%)$ & & \multirow{5}{*}{0.83} \\
\hline & $21-25$ & $319(49.8 \%)$ & \multirow{4}{*}{2.39} & \\
\hline & $26-30$ & $186(29.1 \%)$ & & \\
\hline & $31-35$ & $60(9.4 \%)$ & & \\
\hline & $>35$ & $4(0.6 \%)$ & & \\
\hline \multirow{5}{*}{$\begin{array}{l}\text { Agricultural } \\
\text { Experience }\end{array}$} & $<1$ & $\begin{array}{c}409 \\
(63.91 \%)\end{array}$ & \multirow{5}{*}{1.85} & \multirow{5}{*}{1.31} \\
\hline & $1-4$ & $67(10.5 \%)$ & & \\
\hline & $5-10$ & $67(10.5 \%)$ & & \\
\hline & $11-15$ & $47(7.3 \%)$ & & \\
\hline & $>15$ & $50(7.8 \%)$ & & \\
\hline \multirow{5}{*}{ Business Experience } & $<1$ & $333(52.0 \%)$ & \multirow{5}{*}{2.18} & \multirow{5}{*}{1.44} \\
\hline & $1-4$ & $77(12.0 \%)$ & & \\
\hline & $5-10$ & $81(12.7 \%)$ & & \\
\hline & $11-15$ & $82(12.8 \%)$ & & \\
\hline & $>15$ & $67(10.5 \%)$ & & \\
\hline
\end{tabular}

The structure of major discipline in agriculture with highest $(M=7.26, S D=4.92)$, gender $(M=2.65, S D=0.79)$, batch year $(\mathrm{M}=2.56, \mathrm{SD}=0.95)$, education level $(\mathrm{M}=1.98$, $\mathrm{SD}=1.15), \quad$ age, $\quad(\mathrm{M}=1.30, \quad \mathrm{SD}=0.46), \quad$ from Pakistani graduates. Similarly business experience $(\mathrm{M}=2.06$, $\mathrm{SD}=1.40)$, agricultural experience $(\mathrm{M}=1.68, \mathrm{SD}=1.68)$, family income $(\mathrm{M}=2.01, \mathrm{SD}=0.98)$ respectively from Chinese students contributed. The overall age composition. $(\mathrm{M}=1.46, \quad \mathrm{SD}=0.50)$, business experience $(\mathrm{M}=2.18$, $\mathrm{SD}=1.44)$, monthly income $(\mathrm{M}=2.18, \mathrm{SD}=0.99)$, year of batch $(M=2.46, S D=0.94)$ from first year to fourth year students respectively were perusing their study in the both respective universities presented in table 1.

\section{A. Correlation between different Variables}

The Pearson correlation estimate is proposed to confirm the relationship between dependent variables and independent variables, which are statistically significant and positively perfect, related to the student's entrepreneurial intent and all other variables listed in Table 2. Also, the low magnitude of the relationship confirms the absence of multiple collinearities. However, the correlation between entrepreneurial intentions and alertness is minimal. $(\mathrm{M}=2.27$. $\mathrm{SD}=0.79, \quad \mathrm{r}=0.399, \quad \mathrm{p}>0.01) \quad$ strong uphill positive relationship, whereas creativity $(\mathrm{M}=2.68, \mathrm{SD}=0.65, \mathrm{r}=0.374$, $\mathrm{p}>0.01)$ is the moderate uphill positive relationship among factors. In addition, and locus of control $(\mathrm{M}=2.72 . \mathrm{SD}=0.64$, $\mathrm{r}=0.278, \mathrm{p}>0.01)$ and risk-taking propensity $(\mathrm{M}=2.95$, $\mathrm{SD}=0.65, \mathrm{r}=0.229, \mathrm{p}>0.01)$ and need for achievement with highest $(\mathrm{M}=3.02, \mathrm{SD}=0.72, \mathrm{r}=0.226, \mathrm{p}>0.01)$ respectively shows weak uphill positive relationship with entrepreneurial intentions among graduates in agriculture.

TABLE II. RESULTS OF PEARSON CORRELATION VARIABLES

\begin{tabular}{|c|c|c|c|c|c|c|c|c|}
\hline Variables & M & SD & 1 & 2 & 3 & 4 & 5 & 6 \\
\hline $\begin{array}{l}\text { Entrepreneurial } \\
\text { Intentions }\end{array}$ & 2.59 & 0.79 & 1 & & & & & \\
\hline Alertness & 2.27 & 2.27 & $.399^{* *}$ & 1 & & & & \\
\hline Creativity & 2.68 & 0.65 & $.374^{* *}$ & $.288^{* *}$ & 1 & & & \\
\hline Need for Achievement & 3.02 & 0.72 & $.226^{* *}$ & $.164^{* *}$ & $.404^{* *}$ & 1 & & \\
\hline Risk-taking Propensity & 2.95 & 0.65 & $.229^{* *}$ & $.217^{* *}$ & $.492^{* *}$ & $.428^{* *}$ & 1 & \\
\hline Locus of Control & 2.72 & 0.64 & $.278^{* *}$ & $.212^{* *}$ & $.530^{* *}$ & $.501^{* *}$ & $538^{* *}$ & 1 \\
\hline
\end{tabular}

\section{B. Determinants of Multiple Regression Coefficient Results}

All independent variables (predictors) and dependent (predicted) in the model dimensions were entered simultaneously, results in the model, summary table $\mathrm{R}^{2}=23.9$ taken as set of predictors entrepreneurial alertness, creativity, need for achievement, risk-taking propensity, locus of control account for $23.9 \%$ is interpreted by independent variables to show high significance. The overall regression model is statistically significant. $\mathrm{F}(5,634)=39.831, \mathrm{p}<0.001, \mathrm{R} 2$ $=0.23$ ANOVA with the degree of freedom five and mean square 18.402 in the regression by predictors of graduates entrepreneurial intention in agriculture.

TABLE III. MULTIPLE REGRESSION COEFFICIENTS RESULTS

\begin{tabular}{|c|c|c|c|c|c|c|}
\hline \multirow[t]{2}{*}{ Model } & \multicolumn{3}{|c|}{$\begin{array}{c}\text { Unstandardized Standardized } \\
\text { Coefficients Coefficients }\end{array}$} & \multirow[t]{2}{*}{ ig. } & \multicolumn{2}{|c|}{$\begin{array}{l}\text { Collinearity } \\
\text { Statistics }\end{array}$} \\
\hline & B & Std. Error & Beta & & Toleran & e VIF \\
\hline (Constant) & .648 & .155 & & 4.174 .000 & & \\
\hline Alertness & .369 & .043 & .311 & 8.560 .000 & .908 & 1.101 \\
\hline Creativity & .277 & .052 & .233 & 5.310 .000 & .626 & 1.598 \\
\hline $\begin{array}{c}\text { Need for } \\
\text { Achievement }\end{array}$ & .057 & .045 & .052 & 1.263 .207 & .701 & 1.427 \\
\hline $\begin{array}{l}\text { Risk-taking } \\
\text { Propensity }\end{array}$ & -.013 & .045 & -.013 & -.293 .769 & .629 & 1.590 \\
\hline $\begin{array}{l}\text { Locus of } \\
\text { Control }\end{array}$ & .084 & .056 & .069 & 1.498 .135 & .563 & 1.777 \\
\hline
\end{tabular}

\section{Hypothesis Test Analysis}

In the Table 3 coefficient tests each of predictor at alpha $=0.05$. Alertness and creativity are statistically significant variances. Without multi-collinearity problems, H1 suggests a positive correlation between student alertness and entrepreneurial intent, and entrepreneurship. Related to activities conduct business in a new and unique way. Because choosing an entrepreneur's career requires a high notch of alertness and knowledge. The results show that alertness has a significant impact on college students' entrepreneurial intentions $(\beta=0.311, \mathrm{P}<0.001)$. Therefore, consistent with these results, the investigator's decision $\mathrm{H} 1$ was accepted.

The $\mathrm{H} 2$ study found that there is a definite link between student creativity and entrepreneurial intentions in the 
agricultural sector. To be an entrepreneur still requires a high level of creativity. The results show that creativity has a significant positive impact on university students' entrepreneurial intentions $(\beta=0.233, \mathrm{P}<0.001)$. Therefore, with the support of these results, the researchers decided to accept $\mathrm{H} 2$.

Concerning $\mathrm{H} 3$ shows that there is a positive correlation between students' needs for achievement and entrepreneurial intentions: those who have a high demand for success may be able to bear the risks they take and have a strong passion for their efforts; they may prefer to have a high degree of entrepreneurial intention. However, the results of this study did not confirm the hypothesis 3 . The impact of achievement needs on university students' entrepreneurial will is not significant $(\beta=0.052, \mathrm{P}=0.207)$. Therefore, based on these results, the researcher's decision $\mathrm{H} 3$ was rejected.

$\mathrm{H} 4$ clarifies that there is a positive relationship between risk-taking and student entrepreneurial intentions. This variable represents taking risks while becoming an entrepreneur. A higher level of risk-taking tends to be essential for choosing a startup as a career. The results show that the negative effect of risk-taking tendencies on college students' agricultural entrepreneurial intentions is not significant, $\beta=(-0.013), P=0.769$, consistent with the above results, the researchers decided to refuse to accept $\mathrm{H} 4$.

In assumption, $\mathrm{H} 5$ explains that there is a positive correlation between the student's locus of control and the entrepreneurial intention, which indicates that the individual's trust in his or her achievement depends on his or her behavior. Therefore, high-level control points will tend to take risks, such as agricultural entrepreneurship. The results here describe the insignificant and positive effects of control on student entrepreneurial intentions $(\beta=0.084, p=0.135)$. Therefore, based on these results, the researchers failed to accept H5.

\section{Determinants of variance t-tests on entrepreneurial intention in agriculture}

Overall, independent t-test was significant, between Chinese and Pakistani graduates samples showed significant differences for the observed variables the HZAU $(n=320)$ was associated with $\mathrm{EI}(\mathrm{M}=2.30, \mathrm{SD}=0.78)$ by comparison with the SAU $(\mathrm{n}=320) \mathrm{EI}(\mathrm{M}=2.23, \mathrm{SD}=0.77)$. An analysis of variance to test the difference in means scores between group represents the independent sample t-tests for the university graduate's intention in agriculture at alpha $=0.05$ level denotes that variance of two nations is not approximately to be equal by institutes. Hence, EI [t (638) $=5.77, \mathrm{p}<0.017], \operatorname{AlT}[\mathrm{t}(638)=15.82, \mathrm{p}>0.000]$, CRT $[\mathrm{t}$ $(638)=8.00, \mathrm{p}<0.005], \mathrm{nAch}[\mathrm{t}(638)=1.14 \mathrm{p}=0.235] \mathrm{RTP}$ $[\mathrm{t}(638)=8.16, \mathrm{p}=0.004]$ and LoC $[\mathrm{t}(638)=11.58, \mathrm{p}<$ $0.001]$ presented in Table 4 . The t-test was significant, less than the threshold level except nAch and LoC indicates that there is a significant difference between the score of EI in HZAU and the score of EI towards agriculture entrepreneurship. Therefore, the researcher failed to reject the null hypothesis.
TABLE IV. COMPARISON MEANS, STANDARD DEVIATIONS, TTEST FOR HZAU $(\mathrm{N}=320)$ AND SAU $(\mathrm{N}=320)$.

\begin{tabular}{|c|c|c|c|c|c|}
\hline \multirow[b]{2}{*}{ Variables } & \multicolumn{2}{|c|}{ China } & \multicolumn{2}{|c|}{ Pakistan } & \multirow[b]{2}{*}{$t$-Test } \\
\hline & $\mathbf{M}$ & SD & $\mathbf{M}$ & SD & \\
\hline $\begin{array}{l}\text { Entrepreneurial } \\
\text { Intentions }\end{array}$ & 2.30 & .78 & 2.23 & .77 & $\begin{array}{c}t(638)=5.77, p \\
<0.017\end{array}$ \\
\hline Alertness & 2.30 & .60 & 2.23 & .605 & $\begin{array}{c}t(638)=15.82, p \\
<0.000\end{array}$ \\
\hline Creativity & 2.68 & .60 & 2.68 & .697 & $\begin{array}{c}t(638)=8.00, p \\
<0.005\end{array}$ \\
\hline $\begin{array}{c}\text { Need for } \\
\text { Achievement }\end{array}$ & 3.06 & .73 & 2.97 & .705 & $\begin{array}{c}t(638)=1.14, p \\
=0.235\end{array}$ \\
\hline $\begin{array}{l}\text { Risk-taking } \\
\text { Propensity }\end{array}$ & 2.99 & .73 & 2.91 & .783 & $\begin{array}{c}t(638)=8.16, p \\
<0.004\end{array}$ \\
\hline Locus of Control & 2.72 & .64 & 2.71 & .643 & $\begin{array}{c}t(638)=0.284, p \\
=0.594\end{array}$ \\
\hline
\end{tabular}

The male $(\mathrm{n}=343)$ was associated with EI $(\mathrm{M}=2.52$, $\mathrm{SD}=0.78)$ by comparison with the female $(\mathrm{n}=297)$, EI $(\mathrm{M}=2.67, \mathrm{SD}=0.77)$ at alpha $=0.05$. Analysis of variance between samples showed significant differences for all measured variables at alpha $=0.05$. The $n$ Ach male indicated higher level of EI [ $\mathrm{t}(638)=0.19, \mathrm{p}=0.65]$, AlT [ $\mathrm{t}(638)=$ 4.94, p > 0.027], CrT [t (638) =6.82, p < 0.009], RtP [t (638) $=8.67, \mathrm{p}<0.003]$ and LoC $[\mathrm{t}(638)=11.58, \mathrm{p}<0.001]$ presented in table 5 . The test results show that the differences between the two genders are not approximately equal in gender. An independent t-test is significantly above the threshold level, indicating a significant difference in the scores of female and male graduates in entrepreneurship. The researchers decided to reject the null hypothesis.

TABLE V. COMPARISON MEANS, STANDARD DEVIATIONS, TTEST FOR MALES (N=343) AND FEMALES $(\mathrm{N}=297)$.

\begin{tabular}{|c|c|c|c|c|c|}
\hline \multirow[b]{2}{*}{ Variables } & \multicolumn{2}{|c|}{ Male } & \multicolumn{2}{|c|}{ Female } & \multirow[b]{2}{*}{ t-Test } \\
\hline & M & $\mathrm{SD}$ & M & SD & \\
\hline $\begin{array}{l}\text { Entrepreneurial } \\
\text { Intentions }\end{array}$ & 2.52 & .78 & 2.67 & .77 & $\begin{array}{c}\mathrm{t}(638)=0.19, \mathrm{p} \\
=0.65\end{array}$ \\
\hline Alertness & 2.20 & .64 & 2.34 & .66 & $\begin{array}{l}t(638)=4.94 \\
\mathrm{p}>0.027\end{array}$ \\
\hline Creativity & 2.59 & .66 & 2.78 & .63 & $\begin{array}{c}\mathrm{t}(638)=6.82, \mathrm{p} \\
<0.009\end{array}$ \\
\hline Need for Achievement & 3.00 & .75 & $\begin{array}{l}3 . \\
03\end{array}$ & .68 & $\begin{array}{l}t(638)=1.08 \\
\quad p>0.299\end{array}$ \\
\hline Risk-taking Propensity & 2.85 & .79 & 3.07 & .71 & $\begin{array}{c}\mathrm{t}(638)=8.67, \mathrm{p} \\
<0.003\end{array}$ \\
\hline Locus of Control & 2.64 & .66 & 2.80 & .61 & $\begin{array}{c}\mathrm{t}(638)=11.58 \\
\mathrm{p}<0.001\end{array}$ \\
\hline
\end{tabular}


TABLE VI. MEANS, STANDARD DEVIATIONS, T-TEST FOR BUSINESS EXPERIENCE YES ( $\mathrm{N}=159)$ AND NO $(\mathrm{N}=481)$.

\begin{tabular}{cccccc}
\hline & \multicolumn{2}{c}{ YES } & \multicolumn{2}{c}{ NO } & \\
Variables & M & SD & M & SD & $t$-Test \\
& & & & & \\
\hline $\begin{array}{c}\text { Entrepreneurial } \\
\text { Intentions }\end{array}$ & 2.64 & .72 & 2.57 & .79 & $t(638)=2.67, p>$ \\
& & & & & 0.103
\end{tabular}

The business experience Yes $(\mathrm{n}=159)$ was associated with $\mathrm{EI}(\mathrm{M}=2.64, \mathrm{SD}=0.72)$ by comparison with the No $(\mathrm{n}=481)$ EI $(\mathrm{M}=2.57, \mathrm{SD}=0.79)$ at alpha $=0.05$ level. The results of variance between Chinese and Pakistani graduates having experience in business samples determines significant differences for the examined variables. The alertness [ $\mathrm{t}$ (638) $=0.002, \mathrm{p}=0.964]$, and locus of control $[\mathrm{t}(638)=0.031, \mathrm{p}=$ $861]$ indicated stronger level of intention, and EI [t (638) $=$ 2.67, $\mathrm{p}>0.103]$, creativity [t $(638)=6.98, \mathrm{p}<0.008]$, need for achievement $[\mathrm{t}(638)=0.799, \mathrm{p}<0.372]$, risk-taking propensity $[\mathrm{t}(638)=1.24, \mathrm{p}<0.265]$ presented in Table 6 . The results show that the variance of the business experience is not approximately to be equal by the nation. An independent t-test was significantly above the threshold level, in alertness and locus of control, which demonstrates that there is a significant difference between the score of Chinese and the score of Pakistani graduates business experience towards the agriculture entrepreneurship. The researcher decided to reject the null hypothesis.

TABLE VII. MEANS, STANDARD DEVIATIONS, T-TEST FOR AGRICULTURAL EXPERIENCE YES $(\mathrm{N}=114)$ AND NO $(\mathrm{N}=526)$.

\begin{tabular}{|c|c|c|c|c|c|}
\hline \multirow[b]{2}{*}{ Variables } & \multicolumn{2}{|c|}{ YES } & \multicolumn{2}{|c|}{$\mathrm{NO}$} & \multirow[b]{2}{*}{$t$-Test } \\
\hline & M & SD & M & $\mathrm{SD}$ & \\
\hline $\begin{array}{l}\text { Entrepreneurial } \\
\text { Intentions }\end{array}$ & 2.60 & 0.87 & 2.59 & 0.76 & $\begin{array}{c}t(638)=4.713 \\
p>0.030\end{array}$ \\
\hline Alertness & 2.26 & 0.65 & 2.27 & 0.66 & $\begin{array}{c}t(638)=0.664, p \\
=0.415\end{array}$ \\
\hline Creativity & $2 . .58$ & 0.73 & 2.71 & 0.63 & $\begin{array}{c}t(638)=7.092, p \\
<0.008\end{array}$ \\
\hline $\begin{array}{c}\text { Need for } \\
\text { Achievement }\end{array}$ & 2.71 & 0.63 & 2.91 & 0.72 & $\begin{array}{c}t(638)=2.025, p \\
=0.875\end{array}$ \\
\hline $\begin{array}{l}\text { Risk-taking } \\
\text { Propensity }\end{array}$ & 2.83 & 0.75 & 2.98 & 0.76 & $\begin{array}{c}t(638)=1.499, p \\
=0.221\end{array}$ \\
\hline Locus of Control & 2.67 & 0.67 & 2.98 & 0.63 & $\begin{array}{c}t(638)=1.910, p \\
=0.167\end{array}$ \\
\hline
\end{tabular}

Overall independent t-test was not significant, between Chinese and Pakistani graduates who have agricultural experience samples showed significant differences for the observed variables. The agricultural experience Yes $(n=114)$ was associated with EI $(M=2.60$, $\mathrm{SD}=0.87)$ by comparison with the No $(\mathrm{n}=526) \mathrm{EI}(\mathrm{M}=2.59$, $\mathrm{SD}=0.76)$ at alpha $=0.05$ level. The need for achievement $[\mathrm{t}$ $(638)=2.025, \mathrm{p}<0.875]$ showed greater level of intention and alertness [ $\mathrm{t}(638)=0.664, \mathrm{p}=0.415]$, risk-taking propensity $[\mathrm{t}(638)=1.499, \mathrm{p}<0.221]$ locus of control $[\mathrm{t}$ $(638)=0.031, p=861]$ indicated higher level of intention, whereas EI $[\mathrm{t}(638)=4.713, \mathrm{p}>0.030]$, creativity $[\mathrm{t}(638)=$ $7.092, \mathrm{p}<0.008$ ], presented in table 7 . The results show that the variance of the business experience is not approximately to be equal by agricultural experience, indicating a significant difference between the score of graduates. An independent ttest was significantly above the threshold level, which demonstrates that there is a significant difference between the score of female and the score of male graduates towards the entrepreneurship. The researcher decided to reject the null hypothesis.

\section{CONCLusions}

All the variables in the model taken, as a set of predictor's entrepreneurial alertness (AlT), creativity (CRT), need for achievement (nAch) risk-taking propensity (RTP), Locus of Control (LoC) account for $23.9 \%$ of the criterion variable explained by independent variables shows high significance results tested coefficients predictor at alpha $>0.05$. Therefore, the AlT, and LoC account for statistically significant with no multicollinearity issue in the model by predictors of graduates' entrepreneurial intention in agriculture.

The primary purpose of the study is to determine the personal personality traits affecting the entrepreneurial intentions of both sides' agricultural students. Studies have shown that agrarian students have a higher attitude towards agricultural entrepreneurship, while alertness indicates that Chinese and Pakistani agricultural students have a stronger attitude toward agrarian entrepreneurship. It is positively related to minimum creativity. It is a positive correlation between the factors of the mid-upper slope. Besides, LOC, risk-taking tendencies, and achievement need to indicate that there is a weak up-and-down positive relationship with agricultural entrepreneurial intentions. The study found that students have higher entrepreneurial traits in their chosen psychological characteristics. Entrepreneurial alertness and creativity have a higher impact on students' entrepreneurial intention, while the need for achievement, locus of control points shows a moderate impact and risk-taking tendency. It has a weak stimulating effect on students' entrepreneurial intention agriculture sector.

Similarly, the study found significant differences between male and female intent. The results showed that the gender differences in the two different countries were not nearly equal, and the t-test was significantly higher than the threshold level, which determined that there was a significant difference in the scores of agricultural entrepreneurship between female and male students with business experience and agricultural experience. 
Finally, the t-test results of agricultural intent variation of college graduates are not nearly equal, and the test results are significantly lower than the threshold level, indicating that there is a significant difference in the agricultural intention scores of Chinese and Pakistani agricultural students. There was a considerable difference in the overall independent $\mathrm{t}$ test, indicating a substantial difference in graduate student achievement. It is assumed that young students show significant decision-making intentions for agricultural entrepreneurship, which requires recognition. Entrepreneurship is an excellent way to obtain the results of this study, so there is a strong significant correlation between entrepreneurial intentions and certain personality traits.

The study contributed to the literature on the entrepreneurial intention by testing the role of personality traits model in two diverse economies. The results support and suggested for personality traits attention in the literature. Students from both states significantly intended to start their business. Because study found that entrepreneurship has significant value and potential in agriculture for the borh economies and individuals who set up their business to achieve sustainable socio-economic growth and development. It has led to extensive research on the economic impact to demonstrate the critical drivers of self-employment to use graduates talent for future projection to overcome the burden of unemployment. This study shed lights on an individual's personality traits, in the formation of career intentions in agriculture.

\section{REFERENCES}

Ahmed, S. 2010. The promise of happiness: Duke University Press.

Ajzen, I. 1991. The theory of planned behavior. Org. Beh and Hum.deci. Pro; 2, 179-211.

Ang, S. H., \& Hong, D. G. 2000. The entrepreneurial spirit among East Asian Chinese. Thu. Int. Bsi. Rev; 3, 285-309

Ardichvili, A., Cardozo, R., \& Ray, S. 2003. A theory of entrepreneurial opportunity identification and development. J. of. Bsi. Vent;1, $105-123$

Bird, B. (1988). Implementing entrepreneurial ideas: The case for intention Acad. of. Manage. Rev;3, 442-453.

Blanchflower, D. G., Oswald, A., \& Stutzer, A. 2001. Latent entrepreneurship across nations. Euro. Econ. Rev; 45, 680-691.

Brockhaus Sr, R. H. 1980. Risk-taking propensity of entrepreneurs. Acad. Manage. J;3, 509-520

Butler, J. E., Doktor, R., \& Lins, F. A. 2010. Linking international entrepreneurship to uncertainty, opportunity discovery, and cognition. J. of Int. Entrep;2, 121-134

Buttner, E. H. 1993. Female entrepreneurs: how far have they come? Bsi. Hori.Blo; 36, 59-59

Bygrave, W. D., \& Hofer, C. W. 1992. Theorizing about entrepreneurship. Entrep. Theor. Prac; 2, 13-22

Carvalho, P. M. R. d. 2006. Factors determinants da intenção empreendedora. Fact. Deter. Int

Charney, A. H., \& Libecap, G. D. 2003. The contribution of entrepreneurship education: An analysis of the Berger program. Int. J. Entrep. Edu.,3, 385-418

Coombs, W. T., Holladay, S., Hasenauer, G., \& Signitzer, B. 1994. A comparative analysis of international public relations: Identification and interpretation of similarities and differences between professionalization in Austria, Norway, and the United States. J.Pub.Rel.Res.,1, 23-39

De Pillis, E., \& Reardon, K. K. 2007. The influence of personality traits and persuasive messages on entrepreneurial intention: A crosscultural comparison. Car. Dev. Int;4, 382-396

Díaz-García, M. C., \& Jiménez-Moreno, J. 2010. Entrepreneurial intention: the role of gender. Int. Entrep. Manage. J.,3, 261-283

Dufur, M. J., Parcel, T. L., \& Troutman, K. P. 2013. Does capital at home matter more than capital at school? Social capital effects on academic achievement. Res. Soc. Strat.Mob., 31, 1-21

Erdem, F. 2001. University Faculty of Economics \& Administrative Sciences Faculty J.Acade. Pres., 1-2

Girvan, N. (2009). Implications of the Economic Partnership Agreement (EPA) for the CSME. Soc. nd Econ Std., 91-127

Gorman, G., Hanlon, D., \& King, W. 1997. Some research perspectives on entrepreneurship education, enterprise education and education for small business management: a ten-year literature review. Int. Small. Busi.J.,3, 56-77

Gürol, Y., \& Atsan, N. 2006. Entrepreneurial characteristics amongst university students: Some insights for entrepreneurship education and training in Turkey. Edu. Train., 1, 25-38

Hannon, P. D., Collins, L. A., \& Smith, A. J. 2005. Exploring graduate entrepreneurship: a collaborative, co-learning based approach for students, entrepreneurs, and educators. Ind.High. Edu.,1, 11-23

Hansemark, O. C. 1998. The effects of an entrepreneurship program on the need for achievement and locus of control of reinforcement. Int. J. of Entrep. Beh.Res., 1, 28-50

Hansemark, O. C. 2003. Need for achievement, locus of control and the prediction of business start-ups: A longitudinal study. J.Econ Psych., 3, 301-319.

Hills, G. E., Lumpkin, G. T., \& Singh, R. P. 1997. Opportunity recognition: Perceptions and behaviors of entrepreneurs. Front.Entrep.Res., 4, 168-182

Hisrich, R., Langan-Fox, J., \& Grant, S. 2007. Entrepreneurship research and practice: a call to action for psychology. Amer. Psycho.,6, 575

Hofstede, G. (2010). Geert Hofstede. National cultural dimensions

Hull, D. L., Bosley, J. J., \& Udell, G. G. 1980. Renewing the hunt for the heffalump: identifying potential entrepreneurs by personality characteristics. J.Sml Bsi. Manage. (pre-1986), 18(000001), 11

Jackson, M. C. 2007. Systems Approach To Management: Springer Science \& Business Media

Johnson, B. R. 1990. Toward a multidimensional model of entrepreneurship: The case of achievement motivation and the entrepreneur. Entrep. Theor.Prac., 3, 39-54

Kaish, S., \& Gilad, B. 1991. Characteristics of opportunities search of entrepreneurs versus executives: Sources, interests, general alertness. Journal of business venturing, 6(1), 45-61.

Karanassios, N., Pazarskis, M., Mitsopoulos, K., \& Christodoulou, P. 2006. EU strategies to encourage youth entrepreneurship: Evidence from higher education in Greece. Ind.High. Edu., 1, 43-50

Kirzner, I. M. (1997). Entrepreneurial discovery and the competitive market process: An Austrian approach. J.1 Eecon Lit., 1, 60-85

Koellinger, P., Minniti, M., \& Schade, C. 2013. Gender differences in entrepreneurial propensity. Oxford Bulletin of economics and statistics.,2, 213-234

Kristiansen, S., \& Indarti, N. 2004. Entrepreneurial intention among Indonesian and Norwegian students. J. of Enterp Cult.,01, 55-78

Kuratko, D. F. 2005. The emergence of entrepreneurship education: Development, trends, and challenges. Entrep. Theor.Prac.,5, 577597

Leoni, T., \& Falk, M. 2010. Gender and field of study as determinants of self-employment. Small Bsi Econ.,2, 167-185

Levenburg, N. M., \& Schwarz, T. V. 2008. Entrepreneurial orientation among the youth of India: The impact of culture, education, and environment. T. J. of Entrep., 1, 15-35

Liñán, F., \& Chen, Y. W. 2009. Development and Cross-Cultural application of a specific instrument to measure entrepreneurial intentions. Entrep. Theor.Prac., 3, 593-617

Littunen, H. 2000. Entrepreneurship and the characteristics of the entrepreneurial personality. Int. J.Entrep. Behav.Res.,6, 295-310

Marlow, S. 2002. Women and self-employment: a part of or apart from theoretical construct? The Int. J. of Entrep. \& Innov., 2, 83-91

McClelland, D. C. 1962. Business drive and national achievement. Har. Bsi. Rev., 4, 99-112

Molino, M., Dolce, V., Cortese, C. G., \& Ghislieri, C. 2018. Personality and social support as determinants of entrepreneurial intention. Gender differences in Italy. PloS. one., 6, 2-4

Mueller, S. L., \& Thomas, A. S. 2001. Culture and entrepreneurial potential: A nine-country study of locus of control and innovativeness. J. of Bsi Vent., 1, 51-75

Murphy, G. B., \& Callaway, S. K. 2004. Doing well and happy about it? Explaining variance in entrepreneurs' stated satisfaction with performance. New Eng.J. of Entrep., 2, 15-26

Obschonka, M., Schmitt-Rodermund, E., \& Terracciano, A. (2014). Personality and the gender gap in self-employment: A multination study. PloS one., 8, 3-8

Perry-Smith, J. E., \& Shelley, C. E. 2003. The social side of creativity: A static and dynamic social network perspective. Acade of Manage 
Rev., 1, 89-106

Pervin, L. A. 1970. Personality: Theory, Assessment, and Research. Pervin: John. Wiley \& Sons

Potter, A., \& Heath, J. 2004. The nation of Rebels: Why counterculture became consumer culture: New York: HarperBusiness

Ridha, R. N., \& Wahyu, B. P. 2017. Entrepreneurship intention in the agricultural sector of the young generation in Indonesia. Asia. Pci.J. of Innov.Entrep., 1, 76-89

Robinson, P. B., Stimpson, D. V., Huefner, J. C., \& Hunt, H. K. (1991). An attitude approach to the prediction of entrepreneurship. Enterprise. Theor.Prac., 4, 13-32

Rosti, L., \& Chelli, F. 2005. Gender discrimination, entrepreneurial talent, and self-employment. Small. Bsi. Econo.,2, 131-142

Rotter, J. B. 1966. Generalized expectancies for internal versus external control of reinforcement. Psycho. Monog.Gen.App., 1, 1

Sagie, A., \& Elizur, D. 1999. Achievement motive and entrepreneurial orientation: a structural analysis.Journal of Organizational Behavior: The Int. J. Indus.Occup.Organ. Psycho.Beh., 3, 375 387

Şahin, T. K., \& Asunakutlu, T. 2014. Entrepreneurship in a cultural context: A research on Turks in Bulgaria. Pro-Soc. Behav.Sci., 150, 851861

Sardeshmukh, S. R., \& Smith, R. 2010. An Examination Of Skills And Abilities In A Process Model of Entrepreneurship

Sargani, G. R., Deyi, Z., Magsi, H., Noonari, S., Joyo, M. A., \& Kazmi, S. M. M. 2018. An Empirical Study of Attitude Towards Entrepreneurial Intention among Pakistan and China Agricultural Graduates in Agribusiness. The Int. J. Bsi. Manage.Techno., 5, 21-34.

Şenyuva, E., \& Çalışkan, F. 2014. Lifelong learning perception metaphoric of nurses. Pro.-Soc.Behav. Sci, 152, 372-378

Syrquin, M. 1988. Patterns of structural change. H.book.dev. Econ., 1, 203 273

Thomas, A. S., \& Mueller, S. L. 2000. A case for comparative entrepreneurship: Assessing the relevance of culture. J.Int.Bsi. Std.,2, 287-301

Van der Kuip, I., \& Verheul, I. 1999. Early Development of Entrepreneurial Qualities: T.Rol.Ini. Edu.,2,3-11

Venesaar, U., Kolbe, E., \& Piliste, T. 2006. Students' attitudes and intentions toward entrepreneurship at Tal. Uni.Techno. TUTWPE., 154, $97-$ 114

Verheul, I., Thurik, R., Grilo, I., \& Van der Zwan, P. 2012. Explaining preferences and actual involvement in self-employment: Gender and the entrepreneurial personality. J.Econ.Psycho.,2, 325-341.

Wilson, F., Kickul, J., \& Marlino, D. 2007. Gender, Entrepreneurial SelfEfficacy, and Entrepreneurial Career Intentions: Implications for Entrepreneurship Education. Entrep.Theor.Prac.,3, 387-406

Yordanova, D. I., \& Tarrazon, M.-A. 2010. Gender differences in entrepreneurial intentions: evidence from Bulgaria J.Dev.Entrep.,3, 245-261

Yusof, M., Sandhu, M. S., \& Jain, K. K. 2007. Relationship between psychological characteristics and entrepreneurial inclination: A case study of students at University Tun Abdul Razak (Unitar) J.Asia. Entrep.Sustain., 2, 1-3

Zakaria, e. a. 2014. Assessment Of Agricultural Students Of University For Development Studies Intention To Take Up Self-Employment in Agribusiness

Zhao, H., Seibert, S. E., \& Hills, G. E. 2005. The mediating role of selfefficacy in the development of entrepreneurial intentions. J.App Psycho.,6, 6-12 